\title{
Establishment of Simple and Efficient Methods for Plant Material Harvesting and Storage to Allow DNA Extraction from a Myrtaceae Species with Medicinal Potential
}

\author{
Patrícia Gleydes Morgante $^{1 *}$, Fernanda Figueiredo Vicente ${ }^{1}$, João Vicente Coffani-Nunes ${ }^{1}$ and Paulo Roberto Hrihorowitsch Moreno ${ }^{2}$ \\ ${ }^{1}$ UNESP-Univ Estadual Paulista, Campus Experimental de Registro, Rua Nelson Brihi Badur, 430, Vila Tupi, 11900-000, Registro, SP, Brazil \\ ${ }^{2}$ USP-Universidade de São Paulo, Instituto de Química, Av. Prof. Lineu Prestes 748, bl 11 T, 05508-000, São Paulo, SP, Brazil
}

\begin{abstract}
Genomic DNA isolation is an essential procedure to allow many genetic applications and analyses like that using molecular markers. Obtaining good quality DNA samples is the first step to succeed in such analysis and it depends on effective procedures for harvesting and preserving the plant material, and also for DNA extraction. The use of fresh material is ideal for DNA isolation, however, in studies that involve the harvesting of wild plants this is not always possible, since in most cases, populations are distant from the research laboratory. An alternative is freezing the plant material in liquid nitrogen in the field, but this practice is not feasible in many cases, given the difficulty and danger of transporting the liquid nitrogen tank on places of difficult access. In this study, we present four simple, efficient and low cost methodologies that have been successfully tested for a Myrtaceae species with medicinal potential collected at different biomes, Atlantic Rainforest and Brazilian Savanna (Cerrado). Among the main advantages observed are the reduced use of liquid nitrogen, the use of inexpensive materials and ease of transport and storage of samples. The methods presented here can potentially be applied to other species of this botanical family.
\end{abstract}

Keywords: CTAB extraction; Freezing storage; Silica gel storage; Pimenta pseudocaryophyllus

\begin{abstract}
Abbreviations: DNA: Deoxyribonucleic Acid; CTAB: Cetyltrimethylammonium Bromide; SPVR: Herbarium Hermógenes Leitão Filho; BHCB: Herbarium of the Departamento de Botânica of the Universidade Federal de Minas Gerais; SP: Herbarium of the Botanical Institute of São Paulo; RPPN: Reserva do Patrimônio Particular Natural; PVP: Polivinilpirrolidona; BSA: Bovine Serum Albumin; PCR: Polymerase Chain Reaction; TD-PCR: TouchdownPCR; dNTP: Deoxyribonucleotide
\end{abstract}

\section{Introduction}

The genomic DNA extraction is a primordial stage in several practices and genetic analyses such as those that involves the use of molecular markers, which has had a growing application in the plant systematics and in the population analysis. Studies based in molecular markers can be used successfully in phylogenetic analyses, serving as a great help in matters unresolved by traditional methods of analysis [1-4]; the characterization of genetic diversity of germplasm banks, discrimination among accessions and cultivars, detecting duplications, mixed seeds, drift and uncontrolled intersections $[5,6]$; in determining the degree of relatedness between individuals [7]; the study of population's genetic structure, genetic effects of fragmentation and gene flow [8-11]; construction of genetic maps [12-15]; in studies of polyploidy [16,17] and speciation [18].

All molecular analyses, to be successful, depend on obtaining DNA samples of quality. Therefore, procedures are needed for efficient collection and storage of plant material, as well as isolation of the DNA molecule [19-26]. Experience shows that the use of fresh material is ideal for holding the DNA isolation [21]. However, in studies that involve the collection of wild plants it is not always possible, since in most cases the populations are far from the research laboratory.

An alternative is to perform the freezing of plant material in liquid nitrogen during collection in the field. However, this practice is not feasible in many cases, given the difficulty and danger of transporting liquid nitrogen container in rough terrain and difficult access. Thus, a method much used in the preservation of plant tissue for subsequent DNA extraction is rapid dehydration in silica gel [20,25-27]. This technique is generally simple and efficient, since the dehydrated state, the DNA is less susceptible to chemical or enzymatic degradation [28]. However, some species do not respond well to this type of conservation, with losses in quality of the obtained DNA [24]. Other ways of preserving material may be used; however, not all are simple or require the availability of some specific equipment such as freeze dryers.

Pimenta pseudocaryophyllus (Gomes) Landrum is a tree of the Myrtaceae family, known regionally in Vale do Ribeira (São Paulo, Brazil) with the name of Cataia. The occurrence of the species in Brazil is recorded from southern Bahia to Rio Grande do Sul [29-32]; besides Brazil, the species was also collected in Bolivia [33]. In Vale do Ribeira, the leaves of $P$. pseudocaryophyllus, producing essential oils, provides a tea much appreciated by local communities [29], using it as a diuretic and for fighting colds, flu and fatigue. Its leaves are also used for the preparation of inhalations, alcoholic solution for massage and to obtain the "cachaça with Cataia", typical of the region. This drink is marketed not only in craft stores, but also at service stations along the

*Corresponding author: Patrícia Gleydes Morgante, UNESP-Univ Estadual Paulista, Campus Experimental de Registro, Rua Nelson Brihi Badur, 430, Vila Tupi, 11900-000, Registro, SP, Brazil, Tel: +55 13 3828-3049; Fax: +55 13 3822.2309; E-mail: pgleydes@registro.unesp.br

Received June 24, 2013; Accepted August 23, 2013; Published August 30, 2013

Citation: Morgante PG, Vicente FF, Coffani-Nunes JV, Moreno PRH (2013) Establishment of Simple and Efficient Methods for Plant Material Harvesting and Storage to Allow DNA Extraction from a Myrtaceae Species with Medicinal Potential. Int J Genomic Med 1: 109. doi:10.4172/2332-0672.1000109

Copyright: ( 2013 Morgante PG, et al. This is an open-access article distributed under the terms of the Creative Commons Attribution License, which permits unrestricted use, distribution, and reproduction in any medium, provided the original author and source are credited. 
Citation: Morgante PG, Vicente FF, Coffani-Nunes JV, Moreno PRH (2013) Establishment of Simple and Efficient Methods for Plant Material Harvesting and Storage to Allow DNA Extraction from a Myrtaceae Species with Medicinal Potential. Int J Genomic Med 1: 109. doi:10.4172/23320672.1000109

highway BR 116 in Vale do Ribeira. The plant is obtained by predatory extractive and despite its use for human consumption there is little scientific knowledge about it [34]. Some early studies have showed the presence of chemotypes that may be genetically determined [35], and other investigations have suggested a pharmacological potential for the species [36-38], and it seems that this potential is related to its essential oils $[39,40]$. It is important to note that other species of Pimenta genus have a greatest economic importance and have been the most studied for their pharmacological action [41].

The effective genetic conservation of a species requires the prior knowledge of their reproductive system, structure and genetic diversity. This knowledge allows the design of strategies for recombination, sampling and use of genetic material. In the case of woody species, conservation programs have attempted to emphasize the determination of levels of genetic variability maintained within and among natural populations, as a way to plan for the sustainable use and conservation in situ. This type of conservation is considered ideal for tropical tree species, however, in certain circumstances, ex situ conservation is essential and complementary to in situ, as in the case of rare species in danger of extinction [42].

Considering the lack of knowledge about the structure and genetic diversity of their populations and the strong pressure of exploitation that have suffered in the Vale do Ribeira, it becomes fundamental the development of scientific studies that may provide support for the handling and conservation of $P$. pseudocaryophyllus. Thus, we began a study based on microsatellite markers to evaluate the genetic diversity and structure of natural populations of the species, which occur in plant formations quite distinct as Montana Atlantic Rainforest and Atlantic Rainforest's Restinga from the state of São Paulo (Brazil), and Brazilian Savanna (Cerrado) from the state of Minas Gerais (Brazil). Some of these areas, like Montana Atlantic Rainforest, are very difficult to access, requiring hours of hiking through dense forest. Other areas of study are far from the research laboratory, such as those from the state of Minas Gerais. Therefore, to enable the study of genetic characterization, it was necessary to standardize the methods of collection and preservation of plant material for subsequent DNA extraction that were inexpensive, simple and efficient. The results of this standardization work are presented in this article and are potentially applicable to other species of Myrtaceae.

\section{Material and Methods}

\section{Plant material and origin}

Were collected leaves and branches of $P$. pseudocaryophyllus from three locations: Ilha do Cardoso State Park, São Paulo, Brazil $\left(25^{\circ} 04^{\prime}\right.$ $32^{\prime \prime} \mathrm{S}, 47^{\circ} 55^{\prime} 37^{\prime \prime} \mathrm{W}$ ), where the species is in a Atlantic Rainforest's Restinga vegetation; Serra do Guaraú, Cajati, São Paulo, Brazil $\left(24^{\circ} 47^{\prime}\right.$ $\left.24^{\prime \prime} \mathrm{S}, 48^{\circ} 06^{\prime} 36^{\prime \prime} \mathrm{W}\right)$, in which the plants can be found in so-called "Morro da Cataia", which is characterized by an area of Montana Atlantic Rainforest; and Reserva do Patrimônio Particular Natural (RPPN) Morro Grande, Caldas, Minas Gerais, Brazil (21 ${ }^{\circ} 53^{\prime} 16^{\prime \prime} \mathrm{S}, 46^{\circ}$ 26' 57' W), whose vegetation is a Brazilian Savanna.

Population voucher specimens from Ilha do Cardoso State Park (J. V. Coffani-Nunes 569, date 1/31/2009) and Serra do Guaraú (J. V. Coffani-Nunes 581, date 8/12/2009) were deposited in the Herbarium Hermógenes Leitão Filho (SPVR) and in the Herbarium of the Departamento de Botânica of the Universidade Federal de Minas Gerais (BHCB). Population voucher specimens from RPPN Morro Grande were deposited in the Herbarium SPVR (J. V. Coffani-Nunes
631, date 7/21/2010) and in the Herbarium of the Botanical Institute of São Paulo (SP; Nicolau 3949, date 11/25/2008).

\section{Plant material collection and preservation tests}

Initially, we evaluated three methods $(\mathrm{A}, \mathrm{B}, \mathrm{C})$, described in table 1 , which were applied to 15 plants obtained in the Ilha do Cardoso State Park and 15 plants from Serra do Guaraú. Then a fourth method was evaluated (Table 1, D), using 10 plants of the three populations that composed the study. Plastic bags used remained closed and all the material was protected from light and sun. The storage period before DNA extraction was at least three months in all tests and for all materials collected.

\section{DNA extraction}

DNA extractions were standardized from a CTAB protocol previously described [43], using precipitation with absolute ethanol. It was used $100 \mathrm{mg}$ of fresh plant material and $40 \mathrm{mg}$ of dry plant material (samples preserved in silica gel). The leaf fragments were placed in microcentrifuge tubes and ground in the presence of liquid nitrogen. The extraction buffer proposed by the authors experienced a slight modification, being the concentration of PVP (Polivinilpirrolidona; Vetec, Rio de Janeiro, Brazil) increased to $2 \%$. Rates of $3 \mu \mathrm{L}$ of extracted samples were checked in $0.7 \%$ agarose gel electrophoresis, performing the measurement of the extraction income on the basis of a Lambda DNA marker (Invitrogen, Carlsbad, California, USA) of known concentration ( $200 \mathrm{ng}$ and $300 \mathrm{ng}$ ). The gels were stained with ethidium bromide, visualized under ultraviolet light and photographed with digital equipment PHOTODOC-IT 55 (UVP - Ultra-Violet Products Ltd., Cambridge, UK). Electrophoretic procedures followed standard conditions [44].

\section{Evaluation of the quality of the isolated DNA}

The DNA obtained was analyzed for its quality by hydrolysis with restriction endonucleases and performing PCR reactions.

The hydrolyses were performed with endonucleases HindIII and EcoRV (New England Biolabs, Ipswich, Massachusetts, USA) and used DNA samples from all collection and conservation methods. The reactions were conducted using a final volume of $15 \mu \mathrm{L}$ containing 100 to $200 \mathrm{ng}$ of DNA, 10 Units of enzyme, and 1X enzyme buffer. In reactions with EcoRV, were added $100 \mu \mathrm{g} \cdot \mathrm{mL}^{-1}$ of BSA (Bovine Serum Albumin), following the manufacturer's specifications (New England Biolabs). The hydrolysis reactions remained at $37^{\circ} \mathrm{C}$ for two hours. They were then analyzed by electrophoresis on $0.7 \%$ agarose gel, according to previously described procedure.

PCR reactions were performed with the primer pair Pp1A9

\begin{tabular}{|c|l|}
\hline Method & \multicolumn{1}{c|}{ Collection and conservation } \\
\hline A & $\begin{array}{l}\text { Leaves packed in plastic bags containing silica gel, maintaining at } \\
\text { room temperature until DNA extraction }\end{array}$ \\
\hline B & $\begin{array}{l}\text { Leaves wrapped in paper towels and placed in plastic bags, keeping } \\
\text { at room temperature for } 24 \text { hours, followed by freezing in liquid } \\
\text { nitrogen and stored at }-20^{\circ} \mathrm{C} \text { until DNA extraction }\end{array}$ \\
\hline C & $\begin{array}{l}\text { Leaves wrapped in paper towels and placed in plastic bags, keeping } \\
\text { in cooler with ice for } 24 \text { hours, followed by freezing in liquid nitrogen } \\
\text { and stored at }-20^{\circ} \mathrm{C} \text { until DNA extraction }\end{array}$ \\
\hline D & $\begin{array}{l}\text { Branches bundled with tape and placed in plastic bags, keeping at } \\
\text { room temperature for } 24 \text { to } 48 \text { hours, followed by selection of the } \\
\text { best leaves for storage in silica gel at room temperature until DNA } \\
\text { extraction }\end{array}$ \\
\hline
\end{tabular}

Table 1: Methods of collecting and preserving Pimenta pseudocaryophyllus plant material. 
Citation: Morgante PG, Vicente FF, Coffani-Nunes JV, Moreno PRH (2013) Establishment of Simple and Efficient Methods for Plant Material Harvesting and Storage to Allow DNA Extraction from a Myrtaceae Species with Medicinal Potential. Int J Genomic Med 1: 109. doi:10.4172/23320672.1000109

(GenBank accession number JQ905582), designed from the analysis of a microsatellite-enriched library of $P$. pseudocaryophyllus [45]. DNA samples from all collection and conservation methods were tested. For a final reaction volume of $25 \mu \mathrm{L}$ were used $50 \mathrm{ng}$ of template DNA, $1 \mathrm{X}$ PCR buffer, $1.8 \mathrm{mM}$ magnesium chloride, $0.2 \mathrm{mM}$ of each dNTP, 20 pmol of each primer, and 2 Units of Taq DNA polymerase (Invitrogen). Reactions were brought to the thermal cycler Mastercycler Gradient (Eppendorf AG, Hamburg, Deutschland) and subjected to the following TD-PCR (Touchdown-PCR) program: First step: $94^{\circ} \mathrm{C}$ for $5 \mathrm{~min}$, and eight cycles of $94^{\circ} \mathrm{C}$ for $1 \mathrm{~min}, 56^{\circ} \mathrm{C}$ for $1 \mathrm{~min}\left(-1^{\circ} \mathrm{C} /\right.$ cycle), and $72^{\circ} \mathrm{C}$ for $1 \mathrm{~min}$; second step: 30 cycles of $94^{\circ} \mathrm{C}$ for $1 \mathrm{~min}, 49^{\circ} \mathrm{C}$ for $1 \mathrm{~min}$, and $72^{\circ} \mathrm{C}$ for $1 \mathrm{~min}$ [45]. They were then analyzed by electrophoresis on $3 \%$ agarose gel according to the procedure described above. The TD-PCR program was based on previously described methodology $[46,47]$.

\section{Results and Discussion}

The success of any molecular study involves, firstly, the optimization of methods for collection and storage of plant material and DNA extraction. The aim of the current investigation was to establish practical and inexpensive methodologies to obtain DNA samples in quantity and quality for subsequent studies mediated by PCR amplification.

The first tests involved plants of $P$. pseudocaryophyllus obtained from two populations occurring in different environments in the State of São Paulo, Montana Atlantic Rainforest and Atlantic Rainforest's Restinga. The leaves were collected and stored in three different ways (Table 1, Methods A, B and C) and DNA extractions occurred after three months of storage.

Immediately after DNA isolation, samples were analyzed by electrophoresis on an agarose gel for quantification and visualization of the integrity of the molecules obtained. In all conditions tested, the DNA extracted showed great quantity and quality. The samples were quite intact (Figure 1) since there are no signs of degraded molecules, which are identified as a visible smear in the gel. Quantification revealed it was possible to obtain DNA concentrations ranging from 60 to 100 ng. $\mu \mathrm{L}^{-1}$, results quite suitable for use in PCR reactions.

A fourth method was tested (Table 1, Method D), this time also

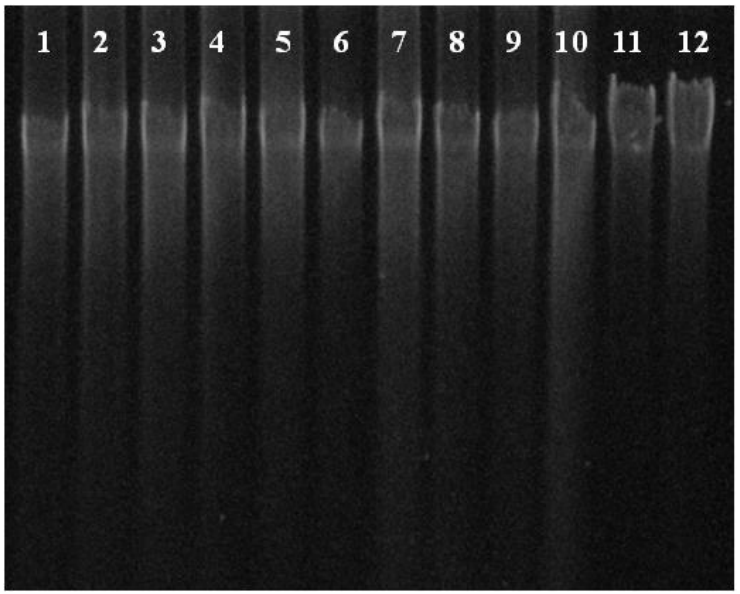

Figure 1: Electrophoresis using DNA samples of Pimenta pseudocaryophyllus plants obtained from Ilha do Cardoso State Park (São Paulo, Brazil). Lanes 1, 2, 3 and 4 were obtained using A method (Table 1); lanes 5, 6 and 7 were obtained using B method (Table 1); lanes 8,9 and 10 were obtained using $C$ method (Table 1); lanes 11 and 12 correspond to Lambda DNA at $200 \mathrm{ng}$ and $300 \mathrm{ng}$ respectively. including plants from the Brazilian Savanna (Cerrado) of Caldas (Minas Gerais). The inclusion of this new procedure in the analysis was intended to evaluate a methodology even more agile and simple to be implemented in the field, collecting up some branches, gathering them and putting them in dark plastic bags for subsequent laboratory screening of the best leaves, and storage in the presence of silica gel.

After three months of storage, were extracted DNA samples and evaluated on agarose gel electrophoresis. The results also demonstrated the achievement of DNA in great quantity and quality (Figure 2), equating the results observed for other methods, both in the integrity of the DNA molecules as the amount obtained.

Once verified the presence of intact DNA molecules and concluded the quantification of samples, it was possible to perform hydrolysis tests with restriction enzymes and PCR reactions. As reported by several authors, the isolation and purification of plant DNA may be problematic due to the co-isolation of polysaccharides, proteins, phenolic compounds and other secondary compounds [43,48-50].

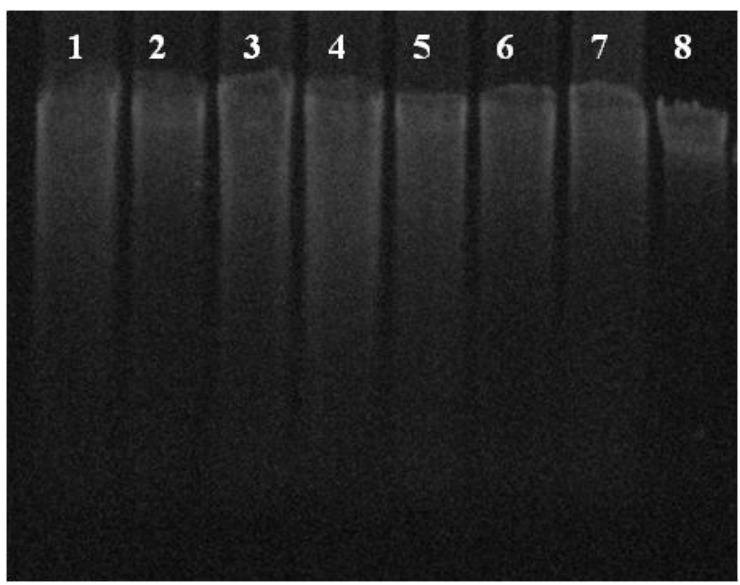

Figure 2: Electrophoresis using DNA samples of Pimenta pseudocaryophyllus plants obtained with D method (Table 1). Lanes 1, 2 and 3 were obtained from RPPN Morro Grande (Caldas, Minas Gerais, Brazil); lanes 4 and 5 were obtained from Ilha do Cardoso State Park (São Paulo, Brazil); lanes 6 and 7 were obtained from Serra do Guaraú (Cajati, São Paulo, Brazil); lane 8 corresponds to Lambda DNA at $200 \mathrm{ng}$
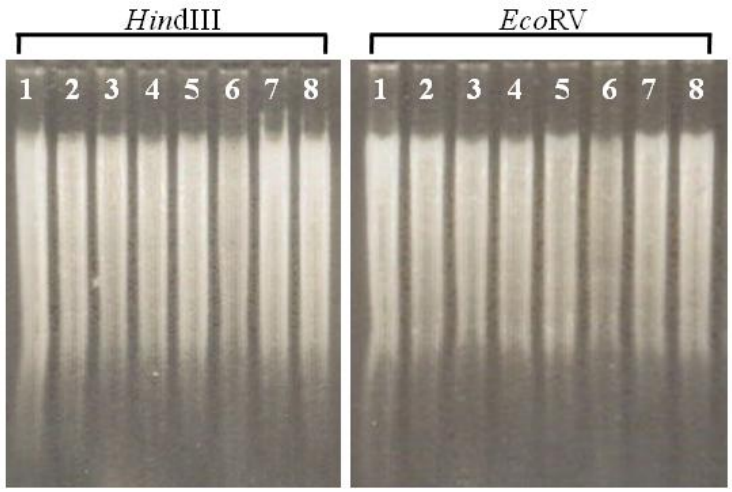

Figure 3: Electrophoresis using DNA samples digested with HindllI and EcoRV restriction enzymes. The gel represents the results obtained for Pimenta pseudocaryophyllus plants from llha do Cardoso State Park (São Paulo, Brazil). Lanes 1 and 2 were obtained using A method (Table 1); lanes 3 and 4 were obtained using B method (Table 1); lanes 5 and 6 were obtained using C method (Table 1); lanes 7 and 8 were obtained using $D$ method (Table 1). 
Citation: Morgante PG, Vicente FF, Coffani-Nunes JV, Moreno PRH (2013) Establishment of Simple and Efficient Methods for Plant Material Harvesting and Storage to Allow DNA Extraction from a Myrtaceae Species with Medicinal Potential. Int J Genomic Med 1: 109. doi:10.4172/23320672.1000109

Such compounds adhere to DNA, and inhibit the action of restriction endonucleases and other enzymes such as polymerases used in PCR reactions $[43,51,52]$. So, these procedures (hydrolysis with restriction enzymes and PCR) are very useful to evaluate the quality of DNA samples.

Thus, the samples were first tested for hydrolysis ability of the restriction endonucleases HindIII and EcoRV. DNA samples from all methods and the three populations were hydrolyzed, and all of them were fully digested (Figure 3), confirming the good quality achieved with the methods evaluated.

The quality of extracted DNA was also verified by PCR reaction, using a pair of primers designed from a $P$. pseudocaryophyllus microsatellite-enriched library [45]. Using DNA samples from all populations and methods tested it was possible to obtain specific PCR products (Figure 4), within the expected size range, calculated on 121 base pairs for the individual plant used in the construction of microsatellite-enriched library [45]. This result denotes the high quality of the DNA isolated in all cases examined.

All procedures tested provided good results, so it is possible to adopt the simpler and independent of freezing for future works. These methods are those that comprise the collection of leaves packed in plastic bags containing silica gel, keeping at room temperature until DNA extraction (Method A), and the obtaining of branches bundled with tape and placed in plastic bags, keeping at room temperature up to 48 hours, followed by selection of the best leaves for storage in silica gel at room temperature until DNA extraction (Method D). Importantly, plants of all populations studied were collected with these methods and many are stored for four years and still provide high quality DNA when used for extractions.

A very important factor that has a direct influence on the extraction yield is the efficiency of grinding tissue. The leaves of $P$. pseudocaryophyllus proved very difficult to be crushed due to its leathery character [53]. It was possible to obtain good results using microcentrifuge tubes of $2 \mathrm{~mL}$ capacity containing strips of the plant material, and grinding them in liquid nitrogen with appropriate pestles [43].

Another factor that appeared to influence the performance of the

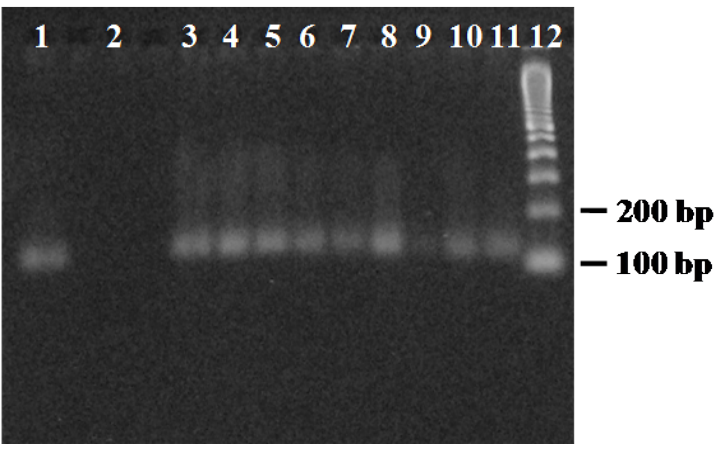

Figure 4: Electrophoresis showing PCR results obtained from DNA samples of Pimenta pseudocaryophyllus using D method (Table 1). Lane 1, results from DNA of the plant used to get the microsatellite library (positive control); lane 2, results from tomato DNA (negative control); lanes 3,4 and 5, results from DNA of plants of the RPPN Morro Grande (Caldas, Minas Gerais, Brazil); lanes 6,7 and 8 , results from DNA of plants of llha do Cardoso State Park (São Paulo, Brazil); lanes 9, 10 and 11, results from DNA of plants of Serra do Guaraú (Cajati, São Paulo, Brazil); lane 12, weight molecular marker, 100 bp DNA Ladder. extraction was the type of plant material collected. It is known that young and tender leaves are best for DNA extraction, since mature tissues normally present phenolic compounds involved in defense against herbivory $[20,21,43,51]$. In the initial stages of the study, some individuals collected showed strong signs of herbivory, and generally had low income or complete absence of DNA after extraction. In situations like this, the best procedure is to seek to collect young and tender leaves. However, when the material is obtained from natural populations in the field and from woody plants, this kind of sampling is not always possible. Thus, a small change in extraction buffer was made by increasing the amount of PVP to $2 \%$. This reagent acts as antioxidant and reduces the undesirable effect of oxidizing phenolic compounds [43], and its concentration in most extraction protocols can vary from 1 to $2 \%[27,43,50,54]$. This adjustment in the composition of the buffer was essential to obtain the desired results.

The procedures presented are simple, efficient and inexpensive, and can potentially be applied to other species of Myrtaceae, although it is advisable to carry out small prior tests for possible adjustments. Among the main advantages observed are the reduced use of liquid nitrogen, the use of inexpensive materials and ease of transport and storage of samples.

\section{Acknowledgement}

The authors thank Marcos Sobral (Departamento de Ciências Naturais Universidade Federal de São João del-Rei, Minas Gerais, Brazil) for confirmation of the species identification, to Inês Cordeiro (Botanical Institute of São Paulo, São Paulo, Brazil) and Sueli Nicolau for collecting plants in Caldas (Minas Gerais), to Anete Pereira de Souza and members of her laboratory (State University of Campinas, Campinas, São Paulo, Brazil) for supporting the construction and analysis of microsatellite-enriched library and the Foundation for the Development of UNESP - FUNDUNESP for financial support (Process 00608/06DFP).

\section{References}

1. Russo CAM (2001) Como escolher genes para problemas filogenéticos específicos. In Biologia Molecular e Evolução (SR Matioli, ed). Holos, Ribeirão Preto, Brazil, 130-136

2. Haston EM, Lewis GP, Hawkins JA (2005) A phylogenetic reappraisal of the Peltophorum group (Caesalpinieae: Leguminosae) based on the chloroplast trnL-F, rbcL and rps16 sequence data. Am J Bot 92: 1359-1371.

3. Salamin N, Hodkinson TR, Savolainen Coates V (2005) Towards building the tree of life: a simulation study for all angiosperm genera. Syst Biol 54: 183-196.

4. Chapman MA, Chang J, Weisman D, Kesseli RV, Burke JM (2007) Universal markers for comparative mapping and phylogenetic analysis in the Asteraceae (Compositae). Theor Appl Genet 115: 747-755.

5. Efombagn IBM, Motamayor JC, Sounigo O, Eskes AB, Nyassé S, et al. (2008) Genetic diversity and structure of farm and GenBank accessions of cacao (Theobroma cacao L.) in Cameroon revealed by microsatellite markers. Tree Genetics \& Genomes 4: 821-831.

6. Xie WG, Zhang XQ, Cai HW, Liu W, Peng Y (2010) Genetic diversity analysis and transferability of cereal EST-SSR markers to orchardgrass (Dactylis glomerata L.). Biochem Syst Ecol 38: 740-749.

7. Weiler RL, Brugnara EC, Bastianel M, Machado MA, Schifino-Wittmann MT, et al. (2009) Teste de paternidade e avaliações agronômicas de possíveis híbridos de tangerineira 'Sunki'. Scientia Agraria 10: 429-435.

8. Dayanandan S, Dole J, Bawa K, Kesseli R (1999) Population structure delineated with microsatellite markers in fragmented populations of a tropical tree, carapa guianensis (Meliaceae). Mol Ecol 8: 1585-1592.

9. Collevatti RG, Grattapaglia D, Hay JD (2001) Population genetic structure of the endangered tropical tree species Caryocar brasiliense, based on variability at microsatellite loci. Mol Ecol 10: 349-356.

10. Takayama K, Tateishi Y, Murata J, Kajita T (2008) Gene flow and population subdivision in a pantropical plant with sea-drifted seeds Hibiscus tiliaceus and its allied species: evidence from microsatellite analyses. Mol Ecol 17: 2730-2742.

11. Bittencourt JVM, Sebbenn AM (2009) Genetic effects of forest fragmentation 
Citation: Morgante PG, Vicente FF, Coffani-Nunes JV, Moreno PRH (2013) Establishment of Simple and Efficient Methods for Plant Material Harvesting and Storage to Allow DNA Extraction from a Myrtaceae Species with Medicinal Potential. Int J Genomic Med 1: 109. doi:10.4172/23320672.1000109

in high-density Araucaria angustifolia populations in Southern Brazil. Tree Genetics \& Genomes 5: 573-582

12. Cregan PB, Jarvik T, Bush AL, Shoemaker RC, Lark KG, et al. (1999) An integrated genetic linkage map of the soybean genome. Crop Science 39: 1464-1490.

13. Faleiro FG, Schuster I, Ragagnin VA, Cruz CD, Corrêa RX, et al. (2003) Caracterização de linhagens endogâmicas recombinantes e mapeamento de locos de características quantitativas associados a ciclo e produtividade do feijoeiro-comum. Pesquisa Agropecuária Brasileira 38: 1387-1397.

14. Song QJ, Marek LF, Shoemaker RC, Lark KG, Concibido VC, et al. (2004) A new integrated genetic linkage map of the soybean. Theor Appl Genet 109: $122-128$.

15. Moretzsohn MC, Leoi L, Proite K, Guimarães PM, Leal-Bertioli SC, et al. (2005) A microsatellite-based, gene-rich linkage map for the AA genome of Arachis (Fabaceae). Theor Appl Genet 111: 1060-1071.

16. Doyle JJ, Doyle JL, Brown AH, Palmer RG (2002) Genomes, multiple origins and lineage recombination in the Glycine tomentella (Leguminosae) polyploid complex: histone H3-D gene sequences. Evolution 56: 1388-1402.

17. Joly S, Bruneau A (2004) Evolution of triploidy in Apios americana (Leguminosae) revealed by genealogical analysis of the histone H3-D gene. Evolution 58: 284-295.

18. Barraclough TG, Vogler AP (2000) Detecting the Geographical Pattern of Speciation from Species-Level Phylogenies. Am Nat 155: 419-434.

19. Doyle JJ, Dickson EE (1987) Preservation of plant samples for DNA restriction endonuclease analysis. Taxon 36: 715-722.

20. Chase MW, Hills HH (1991) Silica gel: An ideal material for field preservation of leaf samples for DNA studies. Taxon 40: 215-220.

21. Sytsma K, Givnish TJ, Smith JF, Hahn WJ (1993) Collection and storage of land plant samples for macromolecular comparisons. Methods Enzymol 224: 23-38.

22. Taylor JW, Swann EC (1994) Dried Samples: Soft Tissues - DNA from Herbarium Specimens. Ancient DNA 167-181.

23. Dessauer HC, Cole CJ, Hafner MS (1996) Collection and storage of tissues. In Molecular Systematic 29-47.

24. Feres F, Souza AP, Amaral MCE, Bittrich V (2005) Avaliação de métodos de preservação de amostras de plantas de Savanas Neotropicais para a obtenção de DNA de alta qualidade para estudos moleculares. Revista Brasileira Botânica 28: 277-283.

25. Witono JR, Kondo K (2006) Modification of DNA isolation protocol from silica gel dried-leaf tissues of Pinanga (Palmae). Berita Biologi 8: 91-97.

26. Whitlock R, Hipperson H, Mannarelli M, Burke T (2008) A high-throughput protocol for extracting high-purity genomic DNA from plants and animals. Mol Ecol Resour 8: 736-741.

27. Fernández JF, Sork VL, Gallego G, López J, Bohorques A, et al. (2000) Cross-amplification of microsatellite loci in a neotropical quercus species and standardization of DNA extration from mature leaves dried in silica gel. Plant Molecular Biology Reporter 18: 397-397.

28. Murray MG, Thompson WF (1980) Rapid isolation of high molecular weight plant DNA. Nucleic Acids Res 8: 4321-4325.

29. Barros F de, Melo MMRF de, Chiea SAC, Kirizawa M, Wanderley MGL, et al. (1991) Flora fanerogâmica da Ilha do Cardoso: Caracterização geral da vegetação e listagem das espécies ocorrentes. Hucitec, São Paulo, Brazil.

30. Koehler A, Galvão F, Longhi SJ (2002) Floresta ombrófila densa altomontana: Aspectos florísticos e estruturais de diferentes trechos na serra do Mar, PR. Ciência Florestal 12: 27-39.

31. Sobral M (2003) A família Myrtaceae no Rio Grande do Sul. Unisinos, São Leopoldo, Brazil.

32. França GS, Stehmann JR (2004) Composição florística e estrutura do componente arbóreo de uma floresta altimontana no município de Camanducaia, Minas Gerais, Brasil. Revista Brasileira de Botânica 27: 19-30.

33. Landrum LR (1986) Campomanesia, Pimenta, Blepharocalyx, Legrandia Acca, Myrrhinium, and Luma (Myrtaceae). Flora Neotropica 45: 1-178.

34. Morgante PG, Coffani-Nunes JV, Moreno PRH, Sobral M (2010) Cataia: Muito consumida, pouco conhecida. In Polo de biotecnologia da Mata Atlântica:
Relatos de pesquisas e outras experiências vividas no Vale do Ribeira (RB Silva, LC Ming, eds.). FUNEP, Jaboticabal, Brazil, 19-40

35. Paula JAM, Ferri PH, Bara MTF, Tresvenzol LMF, Sá FAZ, et al (2011) Infraspecific chemical variability in the essential oils of Pimenta pseudocaryophyllus (Gomes) L. R. Landrum (Myrtaceae). Biochem Syst Ecol 39: 643-650

36. Paula JAM, Paula JR, Bara MTF, Rezende MH, Ferreira HD (2008) Estudo farmacognóstico das folhas de Pimenta pseudocaryophyllus (Gomes) L. R. Landrum - Myrtaceae. Revista Brasileira de Farmacognosia 18: 265-278.

37. Fajemiroye JO, Galdino PM, Alves SF, de Paula JA, de Paula JR, et al. (2012) Involvement of $5-\mathrm{HT} 1 \mathrm{~A}$ in the anxiolytic-like effect of dichloromethane fraction of Pimenta pseudocaryophyllus. J Ethnopharmacol 141: 872-877.

38. de Fátima Lisboa Fernandes O, Costa CR, de Souza Lino Junior R, Vinaud MC, Hasimoto E Souza LK, et al. (2012) Effects of Pimenta pseudocaryophyllus (Gomes) L. R. Landrum, on melanized and non-melanized Cryptococcus neoformans. Mycopathologia 174: 421-428.

39. Lima MEL, Cordeiro I, Young MCM, Sobral MEG, Moreno PRH (2006) Antimicrobial activity of the essential oil from two specimens of Pimenta pseudocaryophyllus (Gomes) Landrum (Myrtaceae) native from São Paulo State Brazil. Pharmacologyonline 3: 589-593.

40. Paula JAM, Paula JR, Pimenta FC, Rezende MH, Bara MT (2009) Antimicrobial activity of the crude ethanol extract from Pimenta pseudocaryophyllus. Pharmaceutical Biology 47: 987-993.

41. Paula JAM, Reis JB, Ferreira LHM, Menezes ACS, Paula JR (2010) Pimenta genus: Botanical aspects, chemical composition and potential. Revista Brasileira de Plantas Medicinais 12: 363-379.

42. Kageyama PY (1987) Conservação "in situ" de recursos genéticos de plantas IPEF 35: 7-37

43. Ferreira ME, Grattapaglia D (1995) Introdução ao uso de marcadores moleculares em análise genética. EMBRAPA-CENARGEN, Brasília, Brazil.

44. Sambrook J, Russell DW (2001) Molecular cloning: A laboratory manual. Cold Spring Harbor Laboratory, New York.

45. Morgante PG, Sebastião I, Silveira LE, Mori GM, Conte M, et al. (2012) Development of microsatellite markers for Pimenta pseudocaryophyllus (Myrtaceae), a wild South American species. Am J Bot 99: e434-436.

46. Don RH, Cox PT, Wainwright BJ, Baker K, Mattick JS (1991) 'Touchdown' PCR to circumvent spurious priming during gene amplification. Nucleic Acids Res 19: 4008.

47. Korbie DJ, Mattick JS (2008) Touchdown PCR for increased specificity and sensitivity in PCR amplification. Nat Protoc 3: 1452-1456.

48. Kidwell KK, Osborn TC (1992) Simple plant DNA isolation procedures. In Plant genomes: Methods for genetic and physical mapping. Kluwer Academic Publishers, London. p.1-13.

49. Mercado JA, Mansouri I, Jiménez-Bermudez S, Pliego-Alfaro F, Quesada MA (1999) A convenient protocol for extraction and purification of DNA from Fragaria. In Vitro Cellular and Developmental Biology Plant 35: 152-153.

50. Romano E, Brasileiro ACM (1999) Extração de DNA de plantas. Biotecnologia 2: $40-43$.

51. Couch JA, Fritz PJ (1990) Isolation of DNA from plants high in polyphenolics Plant Molecular Biology Reporter 8: 8-12.

52. Lodhi MA, Ye GN, Weeden NF, Reisch BI (1994) A simple and efficient method for DNA extraction from grapevine cultivars and Vitis species. Plant Molecular Biology Reporter 12: 6-13.

53. Mazine FF, Souza VC (2008) Myrtaceae dos campos de altitude do Parque Nacional do Caparaó - Espírito Santo/Minas Gerais, Brasil. Rodriguésia 59 57-74

54. Zhang J, Stewart J (2000) Economical and rapid method for the extracting cotton genomic DNA. J Cotton Sci 4: 193-201. 